\title{
Dissolved organic nitrogen and carbon release by a marine unicellular diazotrophic cyanobacterium
}

\author{
Mar Benavides ${ }^{1, *}$, Nona S. R. Agawin ${ }^{2}$, Javier Arístegui ${ }^{1}$, Jan Peene ${ }^{3}$, Lucas J. Stal ${ }^{3,4}$ \\ ${ }^{1}$ Instituto de Oceanografía y Cambio Global, Universidad de Las Palmas de Gran Canaria, \\ 35017 Las Palmas de Gran Canaria, Spain \\ ${ }^{2}$ Departament de Biologia, Universitat de les Illes Balears, 07122 Palma de Mallorca, Spain \\ ${ }^{3}$ Netherlands Institute of Sea Research (NIOZ), Department of Marine Microbiology, 4400 AC Yerseke, The Netherlands \\ ${ }^{4}$ Department of Aquatic Microbiology, IBED, University of Amsterdam, 1090 GE Amsterdam, The Netherlands
}

\begin{abstract}
Dinitrogen $\left(\mathrm{N}_{2}\right)$ fixation rates may be underestimated when recently fixed $\mathrm{N}_{2}$ is released as dissolved organic nitrogen (DON). DON release (DONr) is substantial in the filamentous cyanobacterium Trichodesmium but has never been reported in unicellular diazotrophic cyanobacteria. We used axenic cultures of the marine unicellular diazotroph Cyanothece sp. Miami BG 043511 to measure dissolved organic matter release under $\mathrm{N}_{2}$-fixing conditions. DONr was measured as the transfer of ${ }^{15} \mathrm{~N}_{2}$ from the culture medium to the extracellular DON pool. On average, the DON released represented $\sim 1 \%$ of the total $\mathrm{N}_{2}$ fixed. The average release of dissolved organic carbon, as determined by ${ }^{14} \mathrm{C}$, represented $\sim 2 \%$ of the total carbon fixed. These results suggest that cultured populations of unicellular diazotrophs do not release much dissolved organic matter, but it cannot be excluded that DONr is important in the field when grazers and bacteria are present, or when the organism is exposed to environmental stresses such as turbulence, excess light, temperature changes, or nutrient limitation.
\end{abstract}

KEY WORDS: $\mathrm{N}_{2}$ fixation $\cdot$ DON release $\cdot$ Unicellular cyanobacteria $\cdot$ Cyanothece

\section{INTRODUCTION}

The release of fixed dissolved organic carbon (DOC) by healthy marine plankton has been studied since the 1960s (e.g. Fogg 1962). Release of organic matter in an oligotrophic environment might seem disadvantageous for phytoplankton as it represents a loss of energy and promotes growth of heterotrophic bacteria that compete for nutrients. Hence, these organisms may be outcompeted by those that do not release DOC. The organic carbon may serve as a substrate for autotrophic and heterotrophic plankton (Wood \& Van Valen 1990). Therefore, the release of organic compounds by healthy cells has often been regarded as a paradox in biological oceanography, although it may also have advantages. For example, organic compounds help chelating elements with low availability and solubility such as trace metals (Barbeau 2006). The release of dissolved organic compounds also helps to protect the photosynthetic apparatus in high-light regimes by dissipating excess energy, and shortens the phytoplankton's lag-phase after nutrient-impoverished periods (Wood \& Van Valen 1990, Wannicke et al. 2009).

DOC release (DOCr) by phytoplankton has been widely studied during the past decades (Fogg 1962, Sharp 1977, Wood \& Van Valen 1990). Diazotrophic plankton such as blooming filamentous cyanobacteria are also known to release high amounts of DOC when the bloom decays, feeding grazers and stimulating bacterial production (Sellner 1997). DOCr has also been observed in unicellular cyanobacteria (Bertilsson et al. 2005). However, little is known about the magnitude and ecological signifi- 
cance of the release of dissolved organic nitrogen (DONr) by oceanic diazotrophic cyanobacteria. Most marine dinitrogen $\left(\mathrm{N}_{2}\right)$ fixation field studies have been conducted by measuring the ${ }^{15} \mathrm{~N}$ enrichment of particulate nitrogen (PN) after a certain time of incubation. The filtrates are usually discarded and, therefore, the $\mathrm{N}_{2}$ fixed and subsequently released as dissolved organic or inorganic nitrogen (DON or DIN) is not taken into account. Thus, the amount of $\mathrm{N}_{2}$ that has been fixed is potentially underestimated (Bronk et al. 1994, Gallon et al. 2002, Mulholland 2007).

Global oceanic denitrification exceeds $\mathrm{N}_{2}$ fixation by $200 \mathrm{Tg} \mathrm{N} \mathrm{yr}^{-1}$ (Mahaffey et al. 2005, Codispoti 2007). Recent research indicates that this disequilibrium may be less severe when $\mathrm{N}_{2}$ fixation measurements are expanded to higher latitudes and greater depths (e.g. Moisander et al. 2010), and that these measurements are indeed accurate, which has been questioned (Mohr et al. 2010). Less attention has been paid to the potential underestimation of global oceanic $\mathrm{N}_{2}$ fixation rates caused by not taking into account DONr.

Estimating DONr is also important because it is a source of new nitrogen for autotrophic and heterotrophic plankton (Berman \& Bronk 2003, Bronk et al. 2007). $\mathrm{N}_{2}$ fixed by diazotrophic cyanobacteria can be an important source of nitrogen for other plankton. For instance, transfer of nitrogen from large diazotrophic cyanobacteria to picoplankton has been described for the Baltic Sea (Ohlendieck et al. 2000) and for the Southwest Pacific (Garcia et al. 2007). $\mathrm{N}_{2}$ fixed by the filamentous cyanobacterium Trichodesmium can also sustain the growth of larger autotrophic plankton, such as diatoms (Lee Chen et al. 2011), or even promote harmful algal blooms, as for example those of Karenia brevis off the Florida shelf (Bronk et al. 2004). Agawin et al. (2007) studied interactions between $\mathrm{N}_{2}$-fixing and non- $\mathrm{N}_{2}$-fixing cyanobacteria in a coupled modeling-chemostat culture experiment and found that the DON released by the $\mathrm{N}_{2}$-fixing unicellular cyanobacterium Cyanothece induced a 4-fold increase in the abundance of the non-diazotrophic Synechococcus than it would have achieved in monoculture. This suggests that organic compounds exuded by diazotrophs can fuel primary production and may exert considerable control over the composition of the plankton community in the oligotrophic ocean.

Among marine diazotrophs, Trichodesmium was long thought to be the principal $\mathrm{N}_{2}$ fixer in the oceans (e.g. Capone et al. 1997). However, in the last decade molecular techniques revealed that unicellular diazotrophic cyanobacteria are more abundant and more widely distributed than Trichodesmium (Luo et al. 2012), and their $\mathrm{N}_{2}$ fixation rates are often higher (Falcón et al. 2004, Garcia et al. 2007, Moisander et al. 2010). Field populations of Trichodesmium are known to release up to $\sim 50 \%$ of the recently fixed $\mathrm{N}_{2}$ as DON (Glibert \& Bronk 1994), but in cultures the release is much less (Mulholland et al. 2004). Due to the wider geographical distribution of unicellular diazotrophs, it is necessary to study their DONr activity in order to estimate the potential underestimation of $\mathrm{N}_{2}$ fixation rates. However, direct estimates of DONr by unicellular diazotrophs have not been reported (Mulholland 2007).

DONr rates can be estimated as the difference between gross and net $\mathrm{N}_{2}$ fixation rates, measured by the acetylene reduction assay (ARA) and ${ }^{15} \mathrm{~N}_{2}$ assimilation into biomass, respectively (Gallon et al. 2002, Mulholland et al. 2004). Alternatively, one can measure the ${ }^{15} \mathrm{~N}$ atom \% enrichment of the DON pool and use common tracer equations to estimate DONr rates (e.g. Glibert \& Bronk 1994, Mulholland et al. 2004). Both approaches have been used to indirectly estimate DONr by unicellular diazotrophs. Benavides et al. (2011) performed size-fractionated paired ARA and ${ }^{15} \mathrm{~N}_{2}$ assimilation measurements in the eastern North Atlantic and estimated that the $<10 \mu \mathrm{m}$ diazotrophs potentially released up to $67 \%$ of their recently fixed $\mathrm{N}_{2}$. These facts suggest that unicellular diazotrophs in the field release DON in a manner similar to Trichodesmium. The present study used cultures of Cyanothece sp. Miami BG 043511 (hereafter Cyanothece) as a model organism to test whether the release of dissolved organic matter in unicellular diazotrophic cyanobacteria may be an important process.

\section{MATERIALS AND METHODS}

\section{Culture conditions and experimental setup}

$\mathrm{N}_{2}$ fixation and DONr (Expt 1), and carbon fixation and DOCr (Expt 2) were examined in the present study. Cultures of Cyanothece (formerly classified as Synechococcus) were obtained from the Culture Collection Yerseke (strain CCY 0408). Cultures were grown in $250 \mathrm{ml}$ transparent polypropylene tissue flasks with filter screw caps (VWR) in an illuminated incubator (Snijders ECD01E) at $27^{\circ} \mathrm{C}$ under a 12:12 h light:dark cycle and a light irradiance of $\sim 50 \mu \mathrm{mol}$ photons $\mathrm{m}^{-2} \mathrm{~s}^{-2}$. Standard YBCII medium devoid of a 
source of combined nitrogen (Chen et al. 1996) was used in Expts 1 and 2. In both experiments, 2 replicate cultures were inoculated with $1 \%$ of an exponentially growing stock culture. Expt 1 lasted $10 \mathrm{~d}$ and Expt 2 lasted $8 \mathrm{~d}$. Therefore, 20 and 16 culture replicates were prepared for Expts 1 and 2, respectively. On every experiment day, 2 replicates were sacrificed for the assays and analyses described below.

\section{Chlorophyll, biomass, cell abundance, and cell size}

During both experiments, chlorophyll a (chl a) concentrations, cell abundance, and cell size were monitored daily. For chl a analysis, culture aliquots were filtered onto $25 \mathrm{~mm}$ GF/F filters. Chl a was extracted with $90 \%$ cold acetone for $24 \mathrm{~h}$ and subsequently analyzed by means of a Cary Eclipse Fluorescence Spectrophotometer, previously calibrated with pure chl a (Sigma), and concentrations were calculated using the equations of Ritchie (2006). Cell counts and cell size measurements were performed daily in triplicate vortexed fresh samples using a Multisizer 3 Coulter Counter (Becton Dickinson). Bacterial contaminant numbers were checked daily by phase contrast microscopy and did not exceed $3 \%$ of the cell number of the cyanobacteria.

\section{$\mathbf{N}_{2}$ fixation}

Net $\mathrm{N}_{2}$ fixation was assayed once a day in the middle of the dark period using the stable isotope tracer method of Montoya et al. (1996). For this technique, $125 \mathrm{ml}$ glass vials were filled with culture to overflow, closed with rubber stoppers (allowing the excess culture to escape by a sterile syringe tip piercing the septum) and crimp-sealed with aluminum caps. Trace additions of ${ }^{15} \mathrm{~N}_{2}\left(500 \mu \mathrm{l}_{i} 98.3\right.$ atom $\%{ }^{15} \mathrm{~N}$, Euriso-top) were made using a gas-tight syringe (Hamilton), and the samples were incubated for $3 \mathrm{~h}$. The ${ }^{15} \mathrm{~N}_{2}$ incubated samples were filtered onto precombusted GF/F filters $\left(6 \mathrm{~h}, 450^{\circ} \mathrm{C}\right)$ to obtain the ${ }^{15} \mathrm{~N}$ enrichment and PN concentration.

\section{DONr and intracellular DON production}

In Expt 1, DONr was estimated as the transfer of ${ }^{15} \mathrm{~N}$ from the culture medium to the extracellular DON pool, using the ammonium diffusion technique of Slawyk \& Raimbault (1995) to isolate the labeled DON, and equations reported by Slawyk et al. (1998). In this experiment, we also investigated the $\mathrm{N}_{2}$ fixed as DON but not released during the incubation period (i.e. intracellular DON production, inDONp), computed as inDONp $=\left[\left(R_{\mathrm{inDONf}} / R_{\mathrm{N}_{2}} \times t\right)\right] \times \operatorname{inDONf}$, where $R_{\text {inDONf }}$ represents the excess ${ }^{15} \mathrm{~N}$ enrichment of the intracellular DON pool at the end of the incubation period, $R_{\mathrm{N}_{2}}$ represents the initial ${ }^{15} \mathrm{~N}_{2}$ enrichment of the culture medium, $t$ is the incubation time, and inDONf is the final intracellular DON concentration (i.e. after the $3 \mathrm{~h}$ incubation period).

After incubation and filtration, the filtrate was recovered and stored frozen for extracellular DON analysis. The intracellular DON content of cells was obtained by gently filtering (vacuum pressure $<100 \mathrm{~mm} \mathrm{Hg}$ ) culture aliquots through $3 \mu \mathrm{m}$ pore size, $25 \mathrm{~mm}$ polycarbonate filters, adding $15 \mathrm{ml}$ of boiling Milli-Q water and recovering the filtrate (combined thermal and osmotic shock; Thoresen et al. 1982). For the analysis of ${ }^{15} \mathrm{~N}$-labeled DON, aliquots of the extracellular and intracellular filtrates were poisoned with $1 \% \mathrm{HgCl}_{2}$ after $3 \mathrm{~h}$ of incubation with ${ }^{15} \mathrm{~N}_{2}$. These filtrates were then stored in sterile $50 \mathrm{ml}$ polyethylene tubes at room temperature and in the dark until analysis. To separate DIN (i.e. nitrate + nitrite + ammonium) from DON and analyze the ${ }^{15} \mathrm{~N}$ content of the latter, we followed the 3-step ammonium diffusion methodology proposed by Slawyk \& Raimbault (1995). In Step 1, filtrate subsamples were covered with a screw cap provided with a needle tip and half a GF/F filter humidified with $0.25 \mathrm{~N} \mathrm{H}_{2} \mathrm{SO}_{4}$. $\mathrm{MgO}$ and DeVarda alloy were added to the samples and were subsequently incubated at $50^{\circ} \mathrm{C}$ for $1 \mathrm{wk}$ in order to strip off the DIN as $\left(\mathrm{NH}_{4}\right)_{2} \mathrm{SO}_{4}$. In Step 2, the remaining nitrogen in the subsamples was only DON, which was oxidized to DIN by adding a solution composed of $\mathrm{K}_{2} \mathrm{~S}_{2} \mathrm{O}_{8}, \mathrm{NaOH}$, and $\mathrm{H}_{3} \mathrm{BO}_{3}$. Finally, in Step 3, the remaining nitrogen was removed by repeating Step 1.

$\mathrm{PN}$, particulate carbon $(\mathrm{PC})$, and ${ }^{15} \mathrm{~N}$ enrichments were analyzed by means of a Thermo Flash EA 1112 elemental analyzer connected to a Thermo Delta Advantage isotope ratio mass spectrometer (IRMS). DON concentrations were computed by subtracting DIN from total dissolved nitrogen (TDN). The concentrations of TDN were determined by autoclave destruction and the persulfate oxidation method (Valderrama 1981). DIN was analyzed with a SEAL Technicon Autoanalyzer II, following recommendations by Kirkwood (1995). Detection limits were 0.1, 0.03 , and $0.16 \mu \mathrm{M}$ for nitrate, nitrite, and ammonium, respectively. 


\section{Potential underestimation of $\mathbf{N}_{2}$ fixation rates}

Due to the slow dissolution of gaseous ${ }^{15} \mathrm{~N}_{2}$ in water, $\mathrm{N}_{2}$ fixation rates are underestimated to a variable extent when ${ }^{15} \mathrm{~N}_{2}$ is added to the sample as a bubble (Mohr et al. 2010), indicating that previously published $\mathrm{N}_{2}$ fixation rates are likely underestimated. This important observation was published while the experiments reported in the present study were in progress. For consistency, we decided not to apply the new method provided by Mohr et al. (2010), which consists of adding ${ }^{15} \mathrm{~N}_{2}$ dissolved in the culture medium or seawater sample. Alternatively, we provide a second set of $\mathrm{N}_{2}$ fixation, $\mathrm{DONr}$, and inDONp rates estimated using the \% dissolution of a ${ }^{15} \mathrm{~N}_{2}$ bubble after our period of incubation. After $3 \mathrm{~h}$, the \% dissolution of a ${ }^{15} \mathrm{~N}_{2}$ bubble into YBCII medium at $27^{\circ} \mathrm{C}$ is $28.8 \%$ (W. Mohr pers. comm.).
Samples for the analysis of the intracellular DOC and extracellular DOC concentrations were taken at the end of incubations and analyzed with a Skalar Formacs TOC continuous flow analyzer, previously calibrated with potassium hydrogen phthalate.

\section{RESULTS}

\section{Growth and biomass}

Cell number and the biomass indices chl $a_{1} \mathrm{PN}$, and PC were used to estimate cell division rate and growth rate of the Cyanothece cultures. These variables showed similar patterns in all experiments (Fig. 1). Based on the increase in cell number, the average division rate was $0.64 \mathrm{~d}^{-1}$ and the average growth rates were $0.27,0.22$, and $0.23 \mathrm{~d}^{-1}$, in Expt 1

\section{Carbon fixation and DOCr}

In Expt 2, we tested carbon fixation, DOCr, and intracellular DOC production (inDOCp) by Cyanothece. We incubated $50 \mathrm{ml}$ of culture for $3 \mathrm{~h}$ during the middle of the light period with $100 \mathrm{\mu l}$ of $1057 \mathrm{kBq} \mathrm{ml}{ }^{-1}$ $\mathrm{NaH}^{14} \mathrm{CO}_{3}$ (American Radiolabeled Chemicals). The initial $\mathrm{CO}_{2}$ concentration was measured by automated titration with a Metrohm Dosimat 765 and a Metrohm 780 pH Meter. GF/F and $3 \mu \mathrm{m}$ polycarbonate filters were used as described above for Expt 1.

After incubation and filtration, filters were transferred to polyethylene scintillation vials (Perkin Elmer Pico Prias) and exposed to $\mathrm{HCl}$ fumes in a desiccator in order to remove the non-incorporated ${ }^{14} \mathrm{C}$. Ultima Gold MV (Perkin Elmer) counting cocktail was added. Non-incorporated ${ }^{14} \mathrm{C}$ in the filtrate was removed by adding $100 \mu \mathrm{l}$ concentrated $\mathrm{HCl}$ to $50 \mathrm{ml}$ samples. The next day, samples were counted using Insta-Gel (Perkin Elmer) counting cocktail. The scintillation counter used was a Packard TRICARB 2300. To avoid radioactive contamination of analysis equipment, parallel culture replicates not incubated with ${ }^{14} \mathrm{C}$ were used to measure final PC concentrations. However, the replicate culture flask used for ${ }^{14} \mathrm{C}$ measurements was split into 2 parts and analyzed separately in order to estimate analytical variability.

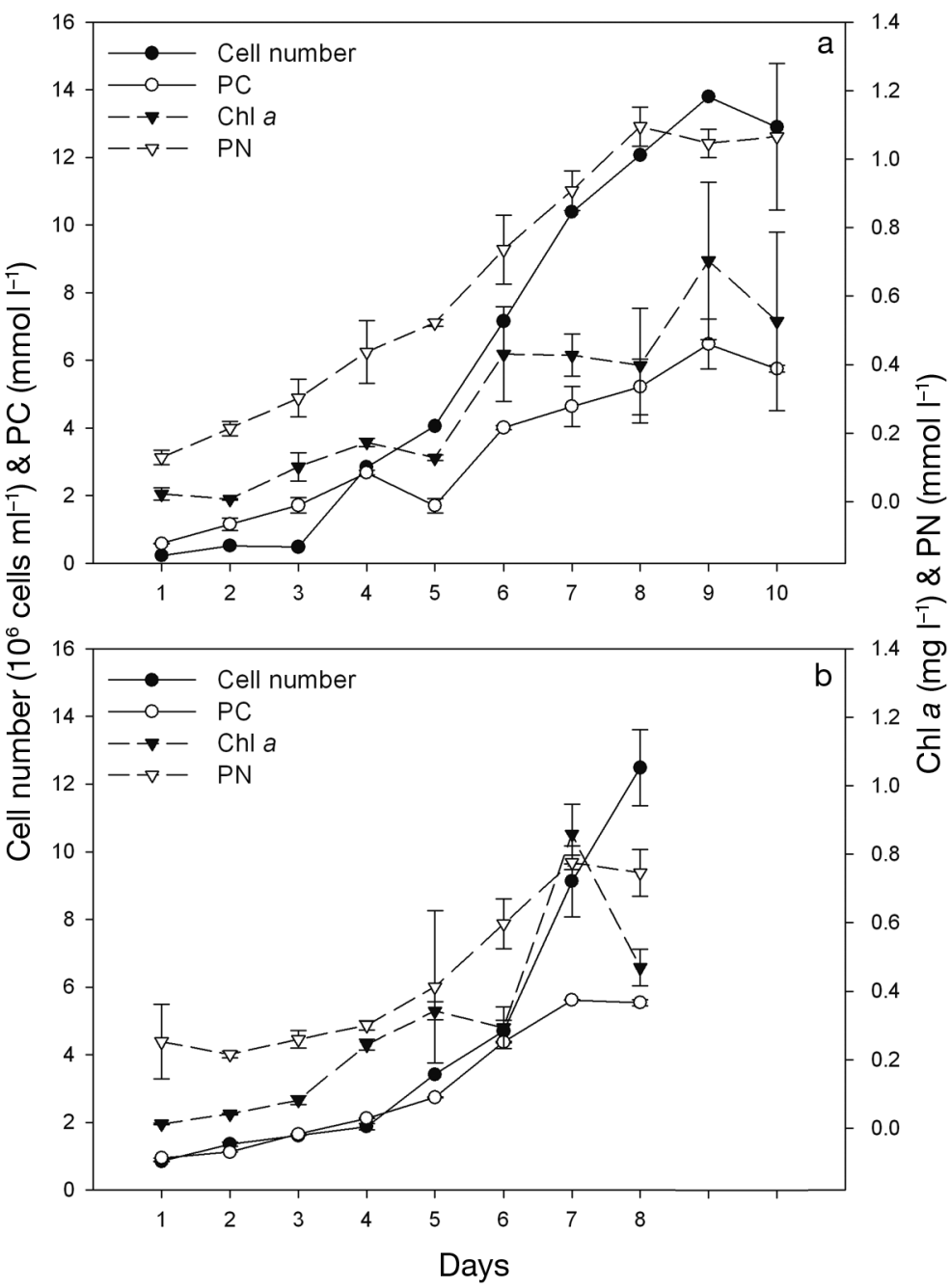

Fig. 1. Cell number, particulate carbon (PC), chlorophyll a (chl a), and particulate nitrogen (PN) in (a) Expt 1 and (b) Expt 2 
as based on chl a, PN, and PC, respectively. In Expt 2, these values were $0.41,0.35,0.24$, and $0.21 \mathrm{~d}^{-1}$, respectively.

\section{Particulate and dissolved nitrogen pools}

The initial and final (before and after the $3 \mathrm{~h}$ incubation period with ${ }^{15} \mathrm{~N}_{2}$ ) concentrations of PN, extracellular and intracellular DON and DIN are shown in Table 1 (Expt 1). The initial concentration of the PN

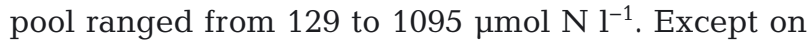
Days 1 and 2, the final amount of PN was always lower than the initial level. However, differences between initial and final PN concentrations were statistically significant ( $t$-test, $p=0.028)$. The initial concentration of extracellular DON and DIN was always smaller than the final concentration, except for extracellular DON on Days 4, 8, and 10. Initial and final extracellular DIN concentrations were statistically different $(p=0.017)$, while differences between extracellular DON concentrations were not $(\mathrm{p}=$ 0.585). Extracellular DON ranged from 10 to $97 \mu \mathrm{mol}$ $\mathrm{N} \mathrm{l}^{-1}$, while DIN values were 1 or 2 orders of magni-

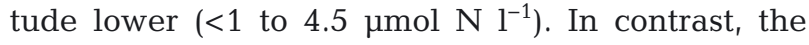
initial concentrations of intracellular DON and DIN were always higher than the final concentrations, except intracellular DON on Day 5, and intracellular DIN on Days 2, 3, and 10. Initial and final intracellular DON concentrations were significantly different $(p=0.027)$, while intracellular DIN concentrations were not $(\mathrm{p}=0.859)$.

While PN and extracellular DON and DIN concentrations increased as the culture grew (during the $10 \mathrm{~d}$ experiment), the intracellular DON and DIN pools showed a different pattern. The intracellular DON pools measured up to $\sim 5-14 \mu \mathrm{mol} \mathrm{N}{ }^{-1}$ during the first $2 \mathrm{~d}$ and last $2 \mathrm{~d}$ of the experiment, while between Days 3 and 8, the concentrations were generally twice as high. Intracellular DIN remained more or less constant, with concentrations between $<1$ and $\sim 2 \mu \mathrm{mol} \mathrm{N}$

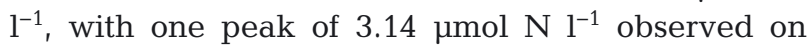
Day 3. The concentration of ${ }^{15} \mathrm{~N}_{2}$ added to the samples $\left(0.16 \mu \mathrm{mol} \mathrm{N}{ }^{-1}\right)$ was taken into account when comparing the initial and final (pre- and post-incubation with ${ }^{15} \mathrm{~N}_{2}$ ) total nitrogen concentrations in all pools. The final total nitrogen concentration (sum of all pools) was lower than the initial one except on Days 1 and 2. Initial total nitrogen concentrations were on average $\sim 15 \%$ higher than final values. This is probably a result of adding the injected ${ }^{15} \mathrm{~N}_{2}$ in the mass balance. Some of this ${ }^{15} \mathrm{~N}_{2}$ is fixed and thus transferred to the particulate and dissolved nitrogen pools, but some

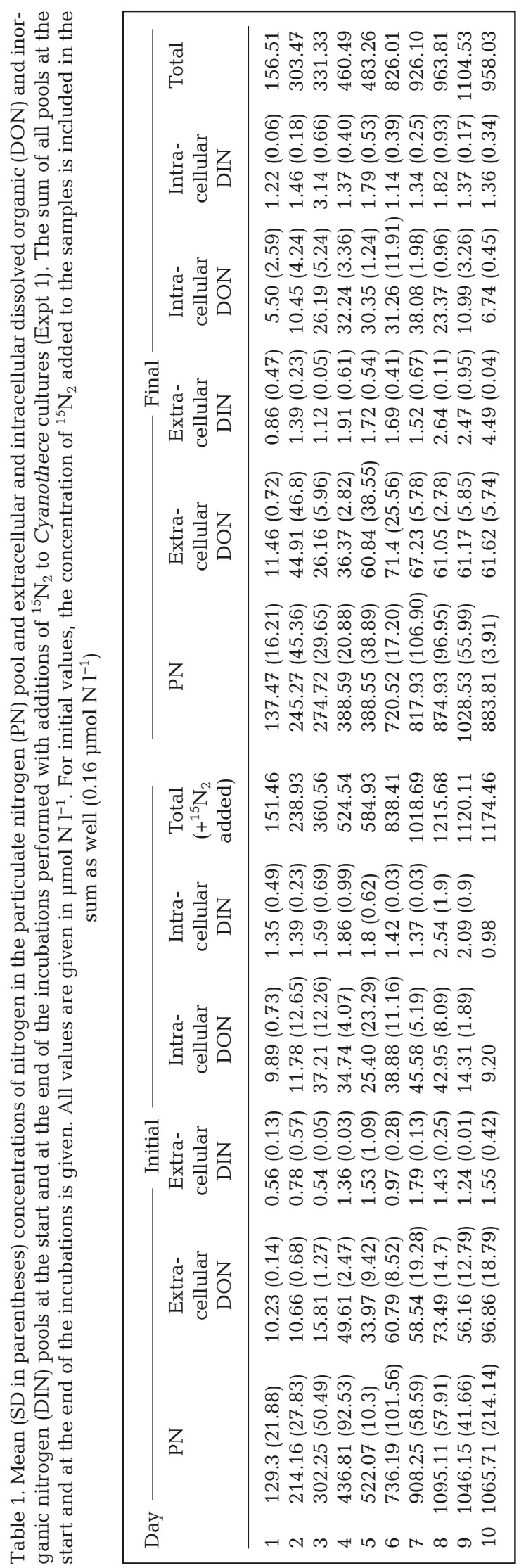


is probably unused or not dissolved into the culture medium during the incubation period (Mohr et al. 2010), and thus not accounted for in the final sum.

The initial and final concentrations of ${ }^{15} \mathrm{~N}$ in the particulate and dissolved pools of Cyanothece cultures during Expt 1 are considered separately in Table 2. Unfortunately, the ${ }^{15} \mathrm{~N}$ enrichment of the DIN pools was not measured and therefore these data are lacking from Table 2. Final concentrations of ${ }^{15} \mathrm{~N}$ in the PN pool were larger than the initial ones, except on Days 5, 8, and 10. Differences between initial and final ${ }^{15} \mathrm{~N}$ concentrations of the PN pool were not statistically significant ( $t$-test, $\mathrm{p}=0.117$ ). However, Montoya et al. (1996) considered a minimum acceptable change of $\delta^{15} \mathrm{~N}$ between the initial and the final PN sample of $4 \%$. The difference between the final and initial $\delta^{15} \mathrm{~N}$ values of PN in our experiments ranged between 66 and $\sim 1400$ (data not shown); hence, we are convinced that the $\mathrm{N}_{2}$ fixation rates presented here are accurate.

The final concentration of ${ }^{15} \mathrm{~N}$ (sum of all pools) was higher than the initial sum on Days 1 to 3 , indicating an excess recovery of ${ }^{15} \mathrm{~N}$. This imbalance is probably due to the low intracellular and extracellular DON concentrations measured on these days. However, the mean \pm SD percentage recovery for the rest of the experiment (Days 4 to 10 ) was $99.08 \pm 10.41 \%$.

\section{$\mathrm{N}_{2}$ fixation, $\mathrm{DONr}$, and inDONp}

When considering the complete dissolution of the ${ }^{15} \mathrm{~N}_{2}$ bubble (tracer method of Montoya et al. 1996), net $\mathrm{N}_{2}$ fixation rates (assimilation of ${ }^{15} \mathrm{~N}_{2}$ into bio- mass) started at $3.66 \mu$ mol $\mathrm{N}^{-1} \mathrm{~h}^{-1}$ on Day 1, peaked at $7.36 \mu \mathrm{mol} \mathrm{N} \mathrm{l}^{-1} \mathrm{~h}^{-1}$ on Day 2, and then decreased to $\sim 2 \mu \mathrm{mol} \mathrm{N}{ }^{-1} \mathrm{~h}^{-1}$ at the end of Expt 1 (Table 3). When only $28.8 \%$ dissolution of the ${ }^{15} \mathrm{~N}_{2}$ bubble was considered, all rates increased $\sim 2.5$-fold and followed the same temporal pattern.

DONr peaked on Day 2 with rates of 0.07 and

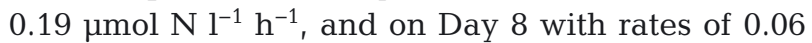

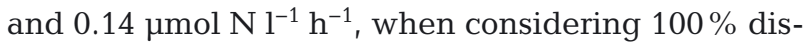
solution and $28.8 \%$ dissolution of the ${ }^{15} \mathrm{~N}_{2}$ bubble, respectively. In the middle of the experiment, DONr

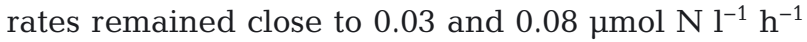
(100 and $28.8 \%{ }^{15} \mathrm{~N}_{2}$ dissolution, respectively), and were lower on Days 1 and 10. On average, DONr represented $\sim 1 \%$ of the total nitrogen fixed (net $\mathrm{N}_{2}$ fixed + DON released + inDON produced). It should be noted that the 'total $\mathrm{N}_{2}$ fixed' includes recently fixed $\mathrm{N}_{2}$ released as DIN. Unfortunately, the ${ }^{15} \mathrm{~N}$ enrichment in DIN was not measured.

The inDONp rates (transfer of ${ }^{15} \mathrm{~N}_{2}$ to the intracellular DON pool) were generally 1 order of magnitude higher than DONr, with values ranging from 0.003 to

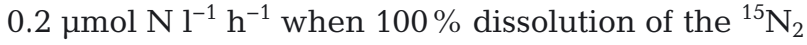
bubble was considered, and 0.008 to $\sim 0.5 \mu \mathrm{mol} \mathrm{N}{ }^{-1}$ $\mathrm{h}^{-1}$ when only $28.8 \%$ dissolution was considered. The overall tendency of inDONp rates was to decrease during the experiment, and the lowest rates were observed on the last $3 \mathrm{~d}$ of Expt 1 (Days 7 to 10).

\section{Carbon pools, carbon fixation, DOCr, and inDOCp}

Rates of net carbon fixation, DOCr, and inDOCp, and the concentration of carbon in the particulate

Table 2. Mean (SD in parentheses) concentrations of ${ }^{15} \mathrm{~N}$ in the particulate nitrogen (PN) and extracellular and intracellular dissolved organic nitrogen (DON) pools, at the start and at the end of the incubations performed with additions of ${ }^{15} \mathrm{~N}_{2}$ to Cyanothece cultures (Expt 1). The sum of ${ }^{15} \mathrm{~N}$ in all pools at the start and at the end of the incubations is given. All values are given in $\mu \mathrm{mol} \mathrm{N} \mathrm{l}{ }^{-1}$. For initial values, the concentration of ${ }^{15} \mathrm{~N}_{2}$ added to the samples is included in the sum as well $(0.16 \mu \mathrm{mol}$ $\mathrm{N} \mathrm{l}^{-1}$ ). A percentage of ${ }^{15} \mathrm{~N}$ recovery is given based on the amount of ${ }^{15} \mathrm{~N}$ in the samples at the start of the incubations compared to the amount of ${ }^{15} \mathrm{~N}$ recovered at the end

\begin{tabular}{|c|c|c|c|c|c|c|c|c|c|}
\hline \multirow{2}{*}{ Day } & \multicolumn{4}{|c|}{ Initial } & & & \multicolumn{3}{|l|}{ Final } \\
\hline & PN & $\begin{array}{c}\text { Extracellular } \\
\text { DON }\end{array}$ & $\begin{array}{c}\text { Intracellular } \\
\text { DON }\end{array}$ & $\begin{array}{c}\text { Total } \\
\left(+{ }^{15} \mathrm{~N}_{2} \text { added }\right)\end{array}$ & PN & $\begin{array}{c}\text { Extracellular } \\
\text { DON }\end{array}$ & $\begin{array}{l}\text { Intracellular } \\
\text { DON }\end{array}$ & Total & $\begin{array}{c}\% \\
\text { recovery }\end{array}$ \\
\hline 1 & $0.53(0.09)$ & $0.04(0.00)$ & 0.02 & 0.75 & $1.06(0.02)$ & $0.04(0.0)$ & $0.05(0.01)$ & 1.15 & 153.33 \\
\hline 2 & $0.82(0.1)$ & 0.04 & $0.02(2.59)$ & 1.04 & $2.02(0.63)$ & $0.17(0.19)$ & $0.06(0.07)$ & 2.25 & 216.35 \\
\hline 3 & $1.15(0.19)$ & $0.05(0.01)$ & $0.03(0.01)$ & 1.39 & $1.73(0.03)$ & $0.08(0.02)$ & $0.12(0.04)$ & 1.93 & 138.85 \\
\hline 4 & $1.65(0.34)$ & $0.15(0.06)$ & $0.08(0.02)$ & 2.04 & $2.06(0.06)$ & $0.16(0.04)$ & $0.13(0.02)$ & 2.35 & 115.19 \\
\hline 5 & $1.95(0.04)$ & $0.12(0.03)$ & $0.1(0.01)$ & 2.33 & $1.95(0.32)$ & $0.14(0.02)$ & $0.1(0.09)$ & 2.19 & 93.99 \\
\hline 6 & $2.74(0.38)$ & $0.29(0.06)$ & $0.09(0.00)$ & 3.28 & $3.17(0.01)$ & $0.2(0.01)$ & $0.12(0.04)$ & 3.49 & 106.40 \\
\hline 7 & $3.38(0.21)$ & $0.25(0.12)$ & $0.09(0.04)$ & 3.88 & $3.42(0.55)$ & $0.25(0.02)$ & $0.15(0.04)$ & 3.82 & 98.45 \\
\hline 8 & $4.08(0.22)$ & $0.29(0.03)$ & 0.12 & 4.65 & $3.68(0.38)$ & $0.24(0.0)$ & 0.15 & 4.07 & 87.53 \\
\hline 9 & $3.87(0.15)$ & $0.2(0.03)$ & 0.08 & 4.31 & $4.22(0.19)$ & $0.24(0.0)$ & $0.06(0.01)$ & 4.52 & 104.87 \\
\hline 10 & $3.96(0.79)$ & $0.26(0.07)$ & 0.04 & 4.42 & $3.51(0.05)$ & $0.31(0.14)$ & $0.03(0.01)$ & 3.85 & 87.10 \\
\hline
\end{tabular}


Table 3. Mean (SD in parentheses) rates of net $\mathrm{N}_{2}$ fixation (A), dissolved organic nitrogen (DON) released (B), intracellular DON produced (inDONp) $(C)$, and total nitrogen fixed $(A+B+C)$ measured considering $100 \%$ dissolution of the ${ }^{15} \mathrm{~N}_{2}$ bubble, and, alternatively, considering $28.8 \%$ dissolution of the ${ }^{15} \mathrm{~N}_{2}$ bubble after a $3 \mathrm{~h}$ incubation period. All rates are given in $\mu$ mol $\mathrm{N}^{-1} \mathrm{~h}^{-1}$. The last column includes the percentage of DON released (DONr) compared to the total $\mathrm{N}_{2}$ fixed $(\mathrm{A}+\mathrm{B}+\mathrm{C}), \mathrm{which}$ is equal for both ${ }^{15} \mathrm{~N}_{2}$ bubble \% dissolutions. Note that the total $\mathrm{N}_{2}$ fixed column does not include any $\mathrm{N}_{2}$ fixed and released as DIN

\begin{tabular}{|c|c|c|c|c|c|c|c|c|c|}
\hline \multirow[t]{2}{*}{ Day } & \multicolumn{4}{|c|}{$100 \%$ dissolution } & \multirow[b]{2}{*}{$\begin{array}{c}\text { Net } \mathrm{N}_{2} \\
\text { fixation }(\mathrm{A})\end{array}$} & \multicolumn{3}{|c|}{$28.8 \%$ dissolution } & \multirow{2}{*}{$\begin{array}{c}\% \\
\mathrm{DONr}\end{array}$} \\
\hline & $\begin{array}{c}\text { Net } \mathrm{N}_{2} \\
\text { fixation (A) }\end{array}$ & $\begin{array}{l}\mathrm{DONr} \\
\text { (B) }\end{array}$ & $\begin{array}{l}\operatorname{inDONp} \\
\text { (C) }\end{array}$ & $\begin{array}{c}\text { Total } N_{2} \\
\text { fixed } \\
(\mathrm{A}+\mathrm{B}+\mathrm{C})\end{array}$ & & $\begin{array}{l}\mathrm{DONr} \\
\text { (B) }\end{array}$ & $\begin{array}{l}\text { inDONp } \\
\text { (C) }\end{array}$ & $\begin{array}{c}\text { Total } N_{2} \\
\text { fixed } \\
(\mathrm{A}+\mathrm{B}+\mathrm{C})\end{array}$ & \\
\hline 1 & $3.66(0.27)$ & $0.00(0.00)$ & $0.06(0.04)$ & 3.72 & $9.46(0.68)$ & $0.01(0.002)$ & $0.16(0.11)$ & 9.62 & 0.08 \\
\hline 2 & $7.36(3.06)$ & $0.07(0.10)$ & $0.15(0.10)$ & 7.59 & $18.9(7.80)$ & $0.19(0.2)$ & $0.39(0.25)$ & 19.25 & 0.98 \\
\hline 3 & $4.85(0.52)$ & $0.04(0.02)$ & $0.10(0.02)$ & 4.99 & $12.3(1.36)$ & $0.09(0.04)$ & $0.26(0.04)$ & 12.51 & 0.72 \\
\hline 4 & $4.28(0.11)$ & $0.03(0.03)$ & $0.20(0.03)$ & 4.51 & $10.8(0.31)$ & $0.08(0.07)$ & $0.49(0.07)$ & 10.95 & 0.69 \\
\hline 5 & 3.44 (1.18) & $0.03(0.01)$ & $0.18(0.01)$ & 3.65 & 8.62 (2.99) & $0.07(0.02)$ & $0.45(0.02)$ & 8.75 & 0.76 \\
\hline 6 & $3.47(0.38)$ & $0.03(0.01)$ & $0.06(0.01)$ & 3.56 & $8.60(0.97)$ & $0.08(0.03)$ & $0.15(0.03)$ & 8.77 & 0.95 \\
\hline 7 & $2.76(1.01)$ & $0.04(0.01)$ & $0.13(0.01)$ & 2.93 & $6.78(2.47)$ & $0.09(0.01)$ & $0.33(0.01)$ & 6.97 & 1.35 \\
\hline 8 & $3.08(0.19)$ & $0.06(0.02)$ & $0.01(0.02)$ & 3.15 & $7.51(0.48)$ & $0.14(0.05)$ & $0.02(0.05)$ & 7.79 & 1.78 \\
\hline 9 & $2.90(0.08)$ & $0.03(0.01)$ & $0.00(0.01)$ & 2.94 & $7.02(0.16)$ & $0.08(0.03)$ & $0.01(0.03)$ & 7.18 & 1.09 \\
\hline 10 & $1.83(0.21)$ & $0.02(0.01)$ & $0.00(0.01)$ & 1.85 & $4.4(0.52)$ & $0.05(0.02)$ & $0.01(0.01)$ & 4.49 & 1.01 \\
\hline
\end{tabular}

and dissolved pools of Cyanothece cultures during Expt 2 are given in Table 4. Carbon fixation rates are given either as net carbon fixed (carbon fixed into biomass), or as 'total carbon fixed' (net carbon fixed + DOC released + inDOC produced). Total carbon

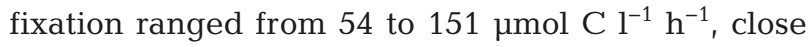
to net carbon fixation, which ranged from 37 to

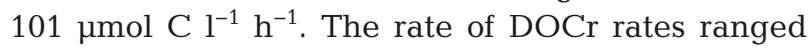

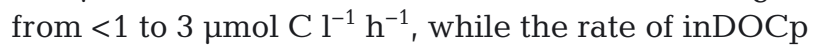
was 1 to 2 orders of magnitude higher, ranging from

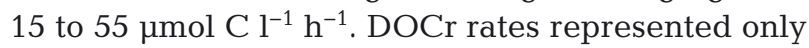
1 to $4 \%$ of the total carbon fixed (average $2 \%$ ). Particulate carbon (PC) ranged from 950 to $5600 \mu \mathrm{mol} \mathrm{C}$ $\mathrm{l}^{-1}$. Extracellular and DOC concentrations ranged

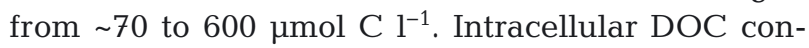
centrations were generally higher than extracellular
DOC concentrations, except on the last $3 \mathrm{~d}$ of Expt 2 (Days 6 to 8).

\section{$\mathrm{C}: \mathrm{N}$ fixation ratios}

The ratios provided here come from 2 different experiments (Expts 1 and 2, see 'Materials and methods'). C:N fixation ratios would be more accurate if both carbon and nitrogen fixation rates had been measured simultaneously in the same culture. However, Expt 2 was done independently because samples treated with radioactivity $\left({ }^{14} \mathrm{C}\right)$ need to be manipulated in a separate laboratory and could not be further processed by elemental analyzer or IRMS.

Table 4. Mean (SD in parentheses) rates of net carbon fixation (A), rate of release of dissolved organic carbon (DOCr) (B), and rate of production of intracellular DOC (inDOCp) $(\mathrm{C})$, as well as the rate of the total carbon fixed $(\mathrm{A}+\mathrm{B}+\mathrm{C})$ measured $u$ sing ${ }^{14} \mathrm{C}$.

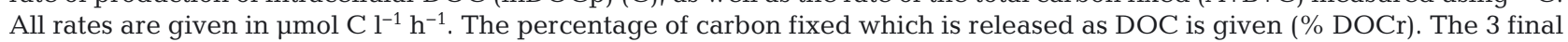
columns represent the concentration of carbon in the particulate carbon (PC) and extracellular and intracellular DOC pools at the end of the incubation period. Concentrations are expressed in $\mu \mathrm{mol} \mathrm{Cl^{-1 }}$

\begin{tabular}{|c|c|c|c|c|c|c|c|c|}
\hline Day & $\begin{array}{c}\text { Net C } \\
\text { fixed (A) }\end{array}$ & $\begin{array}{l}\mathrm{DOCr} \\
\text { (B) }\end{array}$ & $\begin{array}{l}\text { inDOCp } \\
\text { (C) }\end{array}$ & $\begin{array}{c}\text { Total } C \\
\text { fixed }(A+B+C)\end{array}$ & $\% \mathrm{DOCr}$ & $\mathrm{PC}$ & $\begin{array}{l}\text { Extracellular } \\
\text { DOC }\end{array}$ & $\begin{array}{l}\text { Intracellular } \\
\text { DOC }\end{array}$ \\
\hline 1 & $37.47(4.1)$ & $2.41(0.12)$ & $14.55(3.6)$ & $54.43(5.8)$ & 4.43 & $948.92(0.4)$ & $71.39(17.7)$ & $299.97(62.9)$ \\
\hline 2 & $61.38(7.7)$ & $0.70(0.4)$ & $37.44(7.6)$ & 99.52 (12.9) & 0.70 & $1119.28(0.03)$ & $75.42(1.7)$ & $108.84(39.3)$ \\
\hline 3 & $89.31(7)$ & $0.96(0.3)$ & $54.80(6.32)$ & $145.07(11.8)$ & 0.66 & $1651.62(0.17)$ & $111.60(6.7)$ & $172.30(1.9)$ \\
\hline 4 & $82.62(10.3)$ & $1.88(0.2)$ & $52.50(1.2)$ & 137 (16.9) & 1.37 & $2117.82(0.13)$ & $160(2)$ & $306.50(8.7)$ \\
\hline 5 & $97.6(4.5)$ & $3.11(0.8)$ & $46.10(2)$ & $146.81(7.8)$ & 2.11 & $2735.87(1.41)$ & 274.77 (11.3) & $559.24(203.7)$ \\
\hline 6 & 84.7 (1.9) & $2.54(0.2)$ & $46.04(2.8)$ & $133.28(3.4)$ & 1.91 & $4373.13(0.24)$ & $324(28.2)$ & $282.50(172.6)$ \\
\hline 7 & $101(2.7)$ & $2.70(0.1)$ & $47.52(12.2)$ & $151.22(4.1)$ & 1.79 & $5615.35(0.1)$ & $459.10(45)$ & $360.90(40.4)$ \\
\hline 8 & 98.59 (9.01) & $2.43(0.2)$ & $49.34(14.5)$ & $150.36(13.8)$ & 1.62 & $5543(0.9)$ & $599.24(36.9)$ & $297.75(17.1)$ \\
\hline
\end{tabular}


Carbon was fixed at higher rates than nitrogen, as reflected by the high molar ratios of net carbon fixation: net $\mathrm{N}_{2}$ fixation (mol C:mol $\mathrm{N}_{\text {; }}$ Table 5). C:N ratios increased throughout the experiment and exceeded Redfield on almost all experiment days. When net $\mathrm{N}_{2}$ fixation rates were calculated considering $100 \%$ dissolution of the ${ }^{15} \mathrm{~N}_{2}$ bubble, C:N ranged from 8 to $\sim 40$. When $28.8 \%$ dissolution of the ${ }^{15} \mathrm{~N}_{2}$ bubble was assumed, net $\mathrm{N}_{2}$ fixation rates were $\sim 2.5$-fold higher. Consequently, when $28.8 \%$ dissolution of the ${ }^{15} \mathrm{~N}_{2}$ bubble was applied, C:N ratios were lower and did not exceed Redfield, except on Days 1 and 2. From Day 3 on, the C:N ratios ranged from 3 to $\sim 15$.

DOCr:DONr ratios give an estimation of the C:N ratio of the dissolved organic matter released. These ratios were also high, ranging from $\sim 10$ to 116.3 when $100 \%$ dissolution of the ${ }^{15} \mathrm{~N}_{2}$ bubble was considered for the calculation of $\mathrm{N}_{2}$ fixation rates, and from $\sim 4$ to 46.5 when $28.8 \%$ dissolution was assumed. On Day 1, the DONr rates were close to 0 (Table 3), inflating the DOCr:DONr ratios (Table 5).

\section{DISCUSSION}

\section{Measuring $\mathrm{N}_{2}$ fixation and DONr: methodological issues}

There are a number of methodological issues which affect $\mathrm{N}_{2}$ fixation and DONr rates: (1) potential underestimation of $N_{2}$ fixation rates when the ${ }^{15} \mathrm{~N}_{2}$ bubble method is used, (2) unsuccessful recovery of all ${ }^{15} \mathrm{~N}$ added at the end of an incubation period, (3) methodological problems related to DON isolation

Table 5. Net carbon fixation:net $\mathrm{N}_{2}$ fixation and dissolved organic carbon release (DOCr):dissolved organic nitrogen release (DONr) ratios (mol C:mol N). $\mathrm{N}_{2}$ fixation rates were calculated assuming $100 \%$ dissolution of the ${ }^{15} \mathrm{~N}_{2}$ bubble or, alternatively, assuming $28.8 \%$ dissolution of the ${ }^{15} \mathrm{~N}_{2}$ bubble after a $3 \mathrm{~h}$ incubation period

\begin{tabular}{|c|c|c|c|c|}
\hline \multirow[t]{2}{*}{ Day } & \multicolumn{2}{|c|}{$100 \%$ dissolution -} & \multicolumn{2}{|c|}{$28.8 \%$ dissolution } \\
\hline & $\begin{array}{l}\text { Net carbon } \\
\text { fixation:net } \\
\mathrm{N}_{2} \text { fixation }\end{array}$ & DOCr:DONr & $\begin{array}{l}\text { Net carbon } \\
\text { fixation:net } \\
\mathrm{N}_{2} \text { fixation }\end{array}$ & DOCr:DONr \\
\hline 1 & 10.24 & 830.1 & 3.89 & 321.3 \\
\hline 2 & 8.33 & 9.5 & 3.19 & 3.7 \\
\hline 3 & 18.42 & 27.0 & 7.11 & 10.6 \\
\hline 4 & 19.29 & 62.7 & 7.50 & 24.8 \\
\hline 5 & 28.34 & 116.3 & 11.11 & 46.5 \\
\hline 6 & 24.44 & 75.6 & 9.66 & 30.5 \\
\hline 7 & 36.62 & 70.6 & 14.61 & 28.7 \\
\hline 8 & 32.02 & 42.6 & 12.87 & 17.5 \\
\hline
\end{tabular}

for IRMS analysis, (4) artifacts associated with sample manipulation, and (5) intracellular isotopic dilution. Each will be discussed in detail below.

(1) Recently, Mohr et al. (2010) demonstrated that the routinely used ${ }^{15} \mathrm{~N}_{2}$ bubble tracer method underestimates $\mathrm{N}_{2}$ fixation rates due to the slow dissolution of the gas into the medium or the sample seawater. These authors recommended adding ${ }^{15} \mathrm{~N}_{2}$ already dissolved in the water instead of as a bubble, as previously done by Glibert \& Bronk (1994), in order to provide a constant ${ }^{15} \mathrm{~N}$ enrichment of the source $\mathrm{N}_{2}$ pool. The study of Mohr et al. (2010) was published while the experiments reported in the present study were being carried out. As the experiments had already started, we chose not to change our methodology, in order to maintain consistency. To give an approximation of what the rates would have been like using a more realistic dissolution of ${ }^{15} \mathrm{~N}_{2}$ after $3 \mathrm{~h}$ incubation, we recalculated net $\mathrm{N}_{2}$ fixation, $\mathrm{DONr}$, and inDONp rates assuming $28.8 \%$ dissolution of the ${ }^{15} \mathrm{~N}_{2}$ (Table 3), which is the dissolution of ${ }^{15} \mathrm{~N}_{2}$ observed after $3 \mathrm{~h}$ of incubation in YBCII medium at $27^{\circ} \mathrm{C}$ (W. Mohr pers. comm.). When $28.8 \%$ dissolution is applied, net $\mathrm{N}_{2}$ fixation rates explain better the daily PN increase observed (Tables 1 \& 3), corroborating that the ${ }^{15} \mathrm{~N}_{2}$ bubble method underestimates $\mathrm{N}_{2}$ fixation rates.

(2) Another problem often encountered during ${ }^{15} \mathrm{~N}$ experiments is that the label is not fully recovered. Bronk \& Glibert (1994) demonstrated that the fate of this 'missing' ${ }^{15} \mathrm{~N}$ differs between marine systems. In particular, ${ }^{15} \mathrm{~N}$ transfer from the source pool to the DON pool seems to be more important in oligotrophic systems, which supports the need to include DONr measurements in routine nitrogen uptake experiments in order to avoid underestimations (Bronk et al. 1994).

(3) Measuring the ${ }^{15} \mathrm{~N}$ enrichment of the DON pool is prone to difficulties. Extracting DON for isotope analysis is difficult and has prompted intensive discussion in the past (Slawyk et al. 1998, 2000, Bronk \& Ward 2000). The protocol for extracting DON used here (Slawyk \& Raimbault 1995) (see 'Materials and methods') could underestimate DONr because the alkaline hot experimental conditions $\left(60^{\circ} \mathrm{C}\right)$ of the extraction process may hydrolyze some fraction of the DON as ammonium (McCarthy \& Bronk 2008). The alternative DON 
isolation method is the ion retardation column (Bronk \& Glibert 1991); however, this is no longer commercially available in its previous quality and now retains variable amounts of DON, and therefore is not reliable (McCarthy \& Bronk 2008). Hence, consistent DON extraction protocols await development.

(4) Other methodological problems may affect the measurement of DONr, such as the breakage of cells during vacuum filtration and exposure to light and temperature changes during sample manipulation (Feuillade et al. 1990, Wannicke et al. 2009). Vacuum pressure was kept low throughout our experiments ( $<100 \mathrm{~mm} \mathrm{Hg}$ ) and care was taken to avoid temperature and light changes. Light was kept constant in our experiments $\left(\sim 50 \mu \mathrm{mol}\right.$ photons $\left.\mathrm{m}^{-2} \mathrm{~s}^{-2}\right)$, and was well below natural intensities in tropical and subtropical waters where Cyanothece occurs (Langlois et al. 2008). We therefore think that culture settings or sample manipulation did not affect DONr analysis.

(5) The intracellular isotopic dilution in cells with high DON intracellular pools might have affected the measurements of the DONr rates. When the intracellular DON pool and its turnover time are high, isotopic equilibrium between the intracellular pool and the extracellular medium is slow. This causes artificially low DONr rates, as the DON recovered in the extracellular pool is ${ }^{14} \mathrm{~N}$-rich material, which was inside the cell prior to ${ }^{15} \mathrm{~N}_{2}$ addition (Mulholland et al. 2004).

\section{Nitrogen versus carbon metabolism in Cyanothece}

Diazotrophs are known to fix carbon at rates exceeding the $\mathrm{C}: \mathrm{N}$ Redfield ratio (Mulholland et al. 2006, Mulholland 2007). Reasons why this phenomenon occurs in natural populations include (1) substantial nitrogen and/or carbon release due to methodological problems associated with cell manipulation, (2) excess carbon fixation (this ballast may cause sinking of the cells), and (3) excess carbon fixation to decrease cellular oxygen concentrations which may inhibit the nitrogenase (Mehler reactions), or for ATP production (Mulholland 2007). Errors in global estimates of $\mathrm{N}_{2}$ fixation would be lessened if accurate $\mathrm{C}: \mathrm{N}$ fixation ratios of marine diazotrophs were used instead of theoretical elemental stoichiometries (Mulholland 2007).

The DON released during our experiments was similar to the DOC released when expressed as a percentage of the total nitrogen or carbon fixed. On average, Cyanothece released $\sim 1 \%$ of the recently fixed gross $\mathrm{N}_{2}$ as DON, while $\sim 2 \%$ of the gross car- bon fixed was released as DOC. In a series of culture experiments, Wannicke et al. (2009) found that cultured Trichodesmium released $71 \%$ of the fixed $\mathrm{N}_{2}$ as DON and ammonium and $50 \%$ of the carbon fixed as DOC. In our study, DOCr:DONr C:N ratios were high and always exceeded Redfield stoichiometry, with the only exception being Day 2, when $\mathrm{N}_{2}$ fixation rates were calculated using $28.8 \%$ dissolution of the ${ }^{15} \mathrm{~N}_{2}$ bubble (Table 5). These high ratios suggest that the dissolved organic matter released by Cyanothece is enriched in carbon.

It should be noted that DOC and DON were treated as independent pools, but the exudate material of natural populations of diazotrophic organisms is normally composed of both DOC and DON. For example, this is the case for amino acids (Gallon et al. 2002). Whereas eukaryotic phytoplankton organisms are known to exude dissolved organic compounds lacking nitrogen such as carbohydrates (Newell et al. 1972), diazotrophic cyanobacterial exudates are commonly rich in nitrogen (Capone et al. 1994, Mulholland 2007).

\section{DONr by unicellular diazotrophic cyanobacteria}

Trichodesmium is thought to release fixed $\mathrm{N}_{2}$ to provide other trichomes in the colony with nitrogen (Mulholland \& Capone 2000), because not every cell in a trichome and not all trichomes express nitrogenase (Bergman \& Carpenter 1991), or are in the same phase of the cell cycle (Wannicke et al. 2009). Some unicellular cyanobacteria release organic compounds to feed neighboring cells. For example, Gloeothece cells live embedded in a mucilaginous sheath that acts as an 'extracellular vacuole' (Flynn \& Gallon 1990). The advantage, if any, of releasing DON by free-living unicellular diazotrophs is not clear. Possibly free-living unicellular diazotrophs release DON as a response to abiotic factors such as light stress (Wood \& Van Valen 1990). In our study, the DON released represented on average $\sim 1 \%$ of the total $\mathrm{N}_{2}$ fixed by Cyanothece during Expt 1 (Table 3). Given that optimum culture conditions were used, the growth of the cells was balanced and DONr was negligible.

Cultured nitrogen-starved eukaryotic phytoplankton have been reported to release dissolved organic compounds when reaching stationary phase (Newell et al. 1972). In contrast, in our study similar levels of DON and DOC release were observed throughout the experiment (Tables 3 \& 4). A decrease in DONr rates was observed during the last 3 d of Expt 1, 
when the cells were reaching the stationary phase (Fig. 1). We hypothesize that this decrease in DONr rates might have been caused by the increasing availability of DIN and DON in the medium during the last days of Expt 1, and/or the simultaneous uptake of DON by Cyanothece during the experiment (Bronk \& Glibert 1993). Similarly, Bronk (1999) observed a decrease in DONr rates in Synechococcus cultures when the cells became nutrient limited. Cyanothece cells were incubated under a 12:12 h light:dark regime, and DONr rates were measured during the dark phase. However, we were unable to quantify how much of the DON released during the dark phase was taken up during the next light period.

The percentages of fixed $\mathrm{N}_{2}$ released as DON obtained in this study are low $\left(\sim 1 \%\right.$ of total $\mathrm{N}_{2}$ fixation), even lower than those obtained with cultures of Trichodesmium IMS101 ( 8\%; Mulholland et al. 2004), and much lower than in field studies of Trichodesmium ( $50 \%$; Glibert \& Bronk 1994). To our knowledge, there are no reports on DONr by unicellular diazotrophs (Mulholland 2007). Recently, we measured DONr by the $<10 \mu \mathrm{m}$ planktonic fraction in surface waters of the North Atlantic Ocean and estimated that on average $\sim 20 \%$ of the recently fixed $\mathrm{N}_{2}$ was released extracellularly as DON (M. Benavides unpubl.). The $<10 \mu \mathrm{m}$ fraction in natural waters may contain a variety of different diazotrophs, probably mostly UCYN-A and Crocosphaera, which are dominant in this area of the Atlantic (Langlois et al. 2008). Unfortunately, we cannot discern which diazotrophs release DON and which do not from a $<10 \mu \mathrm{m}$ planktonic sample. However, this difference in DONr dynamics between natural and cultured unicellular diazotrophs is comparable to that observed by Glibert \& Bronk (1994) and Mulholland et al. (2004) in natural and cultured populations of Trichodesmium, respectively.

The constantly growing evidence of the diversity and wide distribution of oceanic unicellular diazotrophs emphasizes the need for accurate $\mathrm{N}_{2}$ fixation rates and to provide better estimates of the release of DON by these organisms. The lack of carbon fixation activity in UCYN-A makes them depend on compounds produced by other organisms (Tripp et al. 2010), so it is unlikely that they release any of their recently fixed $\mathrm{N}_{2}$ unless they are under some sort of environmental or predatory stress. Recent research on extracellular polysaccharide production by Crocosphaera (Sohm et al. 2011) suggests that their DONr dynamics in the ocean could be important.
We chose Cyanothece as a model organism because it is easier to grow in culture, facilitating experiments. This diazotroph is similar to Crocosphaera in size $(\sim 2$ to $6 \mu \mathrm{m})$ and in nitrogenase activity patterns. Thus, their organic matter excretion metabolism could indeed be comparable. However, these organisms belong to different UCYN groups. Crocosphaera belongs to UCYN-B (Zehr et al. 2001), while Cyanothece is a polyphyletic group, and currently we do not know with certainty whether strain Miami BG 043511 belongs to group C (Taniuchi et al. 2012). UCYN-A and Crocosphaera are much more abundant in the open ocean than Cyanothece (Luo et al. 2012). Therefore, DONr should be measured in these other species before we draw any conclusion of the importance of DONr in underestimating global $\mathrm{N}_{2}$ fixation rates.

Acknowledgements. We are indebted to M. Houtekamer, C. Kleppe van Zettenand, Lennart van IJzerloo, and the rest of the analytic laboratory team at NIOZ-Yerseke. We also thank J. Ly, J. Kromkamp, H. Bolhuis, H. T. S. Boschker, and S. Malkin for helpful advice on the setup and development of the experiments. We thank D. A. Bronk for many valuable comments on earlier versions of this manuscript and A. Santana for help with data analysis. This work was supported by project CAIBEX (CTM2007-66408-CO2-O2) and HOTMIX (CTM2011-30010-C02-01) to J.A., a Ramón y Cajal grant and project CYFOD (CTM2008-00915-E) to N.S.R.A., and an FPI fellowship (BES-2008-006985) to M.B., all from the Spanish Ministry of Science and Innovation (MICINN).

\section{LITERATURE CITED}

Agawin NSR, Rabouille S, Veldhuis MJW, Servatius L, Hol S, Van Overzee HMJ, Huisman J (2007) Competition and facilitation between unicellular nitrogen-fixing cyanobacteria and non-nitrogen-fixing phytoplankton species. Limnol Oceanogr 52:2233-2248

Barbeau K (2006) Photochemistry of organic iron(III) complexing ligands in oceanic systems. Photochem Photobiol 82:1505-1516

> Benavides M, Agawin NSR, Arístegui J, Ferriol P, Stal LJ (2011) Nitrogen fixation by Trichodesmium and small diazotrophs in the subtropical northeast Atlantic. Aquat Microb Ecol 65:43-53

> Bergman B, Carpenter EJ (1991) Nitrogenase confined to randomly distributed trichomes in the marine cyanobacterium Trichodesmium thiebautii. J Phycol 27:158-165

- Berman T, Bronk DA (2003) Dissolved organic nitrogen: a dynamic participant in aquatic ecosystems. Aquat Microb Ecol 31:279-305

Bertilsson S, Berglund O, Pullin MJ, Chisholm SW (2005) Release of dissolved organic matter by Prochlorococcus. Vie Milieu 55:225-231

Bronk D (1999) Rates of $\mathrm{NH}_{4}{ }^{+}$uptake, intracellular transformation and dissolved organic nitrogen release in two clones of marine Synechococcus spp. J Plankton Res 21: 1337-1353

> Bronk DA, Glibert PM (1991) A ${ }^{15} \mathrm{~N}$ tracer method for the 
measurement of dissolved organic nitrogen release by phytoplankton. Mar Ecol Prog Ser 77:171-182

- Bronk DA, Glibert PM (1993) Application of a ${ }^{15} \mathrm{~N}$ tracer method to the study of dissolved organic nitrogen uptake during spring and summer in Chesapeake Bay. Mar Biol 115:501-508

Bronk DA, Glibert PM (1994) The fate of the missing ${ }^{15} \mathrm{~N}$ differs among marine systems. Limnol Oceanogr 39: 189-195

Bronk DA, Ward BB (2000) Magnitude of dissolved organic nitrogen release relative to gross nitrogen uptake in marine systems. Limnol Oceanogr 45:1879-1883

> Bronk DA, Glibert PM, Ward BB (1994) Nitrogen uptake, dissolved organic nitrogen release, and new production. Science 265:1843-1846

Bronk DA, Sanderson MP, Mulholland MR, Heil CA, O'Neil JM (2004) Organic and inorganic nitrogen uptake kinetics in field populations dominated by Karenia brevis. In: Steidinger KA, Vargo GA, Heil CA (eds) Harmful algae 2002. Florida Fish and Wildlife Conservation Commission, St. Petersburg, FL, p 80-82

> Bronk DA, See JH, Bradley P, Killberg L (2007) DON as a source of bioavailable nitrogen for phytoplankton. Biogeosciences 4:283-296

> Capone DG, Ferrier MD, Carpenter EJ (1994) Amino acid cycling in colonies of the planktonic marine cyanobacterium Trichodesmium thiebautii. Appl Environ Microbiol 60:3989-3995

Capone DG, Zehr JP, Paerl H, Bergman B, Carpenter EJ (1997) Trichodesmium, a globally significant marine cyanobacterium. Science 276:1221-1229

Chen YB, Zehr JP, Mellon M (1996) Growth and nitrogen fixation of the diazotrophic filamentous non heterocystous cyanobacterium Trichodesmium sp. IMS 101 in defined media: evidence for a circadian rhythm. J Phycol 32:916-923

> Codispoti LA (2007) An oceanic fixed nitrogen sink exceeding $400 \mathrm{Tg} \mathrm{N} \mathrm{a}{ }^{-1}$ vs the concept of homeostasis in the fixed-nitrogen inventory. Biogeosciences 4:233-253

Falcón LI, Carpenter EJ, Cipriano F, Bergman B, Capone DG (2004) $\mathrm{N}_{2}$ fixation by unicellular bacterioplankton from the Atlantic and Pacific Oceans: phylogeny and in situ rates. Appl Environ Microbiol 70:765-770

Feuillade M, Feuillade J, Fiala V (1990) The effect of light on the release of organic compounds by the cyanobacterium Oscillatoria rubescens. Aquat Sci 52:345-359

Flynn KJ, Gallon JR (1990) Changes in intracellular and extracellular $\alpha$-amino acids in Gloeothece during $\mathrm{N}_{2}$-fixation and following addition of ammonium. Arch Microbiol 153:574-579

Fogg GE (1962) Extracellular products. In: Lewin RA (ed) Physiology and biochemistry of algae. Academic Press, New York, NY, p 475-489

Gallon JR, Evans AM, Jones DA, Albertano P and others (2002) Maximum rates of $\mathrm{N}_{2}$ fixation and primary production are out of phase in a developing cyanobacterial bloom in the Baltic Sea. Limnol Oceanogr 47:1514-1521

> Garcia N, Raimbault P, Sandroni V (2007) Seasonal nitrogen fixation and primary production in the Southwest Pacific: nanoplankton diazotrophy and transfer of nitrogen to picoplankton organisms. Mar Ecol Prog Ser 343:25-33

Glibert PM, Bronk DA (1994) Release of dissolved organic nitrogen by marine diazotrophic cyanobacteria, Trichodesmium spp. Appl Environ Microbiol 60:3996-4000

Kirkwood DS (1995) Nutrients: practical notes on their determination in seawater. ICES Techniques on Marine Environmental Sciences Report 17. International Council for the Exploration of the Seas, Copenhagen

Langlois RJ, Hummer D, LaRoche J (2008) Abundances and distributions of the dominant nifH phylotypes in the northern Atlantic Ocean. Appl Environ Microbiol 74: 1922-1931

> Lee Chen Y, Tuo S, Chen HY (2011) Co-occurrence and transfer of fixed nitrogen from Trichodesmium spp. to diatoms in the low-latitude Kuroshio Current in the NW Pacific. Mar Ecol Prog Ser 421:25-38

> Luo YW, Doney SC, Anderson LA, Benavides M and others (2012) Database of diazotrophs in global ocean: abundance, biomass and nitrogen fixation rates. Earth Syst Sci Data 4:47-73

Mahaffey C, Michaels AF, Capone DG (2005) The conundrum of marine $\mathrm{N}_{2}$ fixation. Am J Sci 305:546-595

McCarthy MD, Bronk DA (2008) Analytical methods for the study of nitrogen. In: Capone DG, Bronk DA, Mulholland MR, Carpenter EJ (eds) Nitrogen in the marine environment, 2nd edn. Academic Press, San Diego, CA, p 1219-1275

Mohr W, Großkopf T, Wallace DWR, LaRoche J (2010) Methodological underestimation of oceanic nitrogen fixation rates. PLoS ONE 5:e12583

Moisander PH, Beinart RA, Hewson I, White AE and others (2010) Unicellular cyanobacterial distributions broaden the oceanic $\mathrm{N}_{2}$ fixation domain. Science 327 : 1512-1514

Montoya JP, Voss M, Kähler P, Capone D (1996) A simple, high-precision, high-sensitivity tracer assay for $\mathrm{N}_{2}$ fixation. Appl Environ Microbiol 62:986-993

- Mulholland MR (2007) The fate of nitrogen fixed by diazotrophs in the ocean. Biogeosciences 4:37-51

> Mulholland MR, Capone D (2000) The nitrogen physiology of the marine $\mathrm{N}_{2}$-fixing cyanobacteria Trichodesmium spp. Trends Plant Sci 5:148-153

> Mulholland MR, Bronk DA, Capone DG (2004) Dinitrogen fixation and release of ammonium and dissolved organic nitrogen by Trichodesmium IMS101. Aquat Microb Ecol 37:85-94

Mulholland MR, Bernhardt PW, Heil CA, Bronk DA, O'Neil JM (2006) Nitrogen fixation and release of fixed nitrogen by Trichodesmium spp. in the Gulf of Mexico. Limnol Oceanogr 51:1762-1776

Newell BS, Dalmont G, Grant BR (1972) The excretion of organic nitrogen by marine algae in batch and continuous culture. Can J Bot 50:2605-2611

Ohlendieck U, Stuhr A, Siegmund H (2000) Nitrogen fixation by diazotrophic cyanobacteria in the Baltic Sea and transfer of the newly fixed nitrogen to picoplankton organisms. J Mar Syst 25:213-219

> Ritchie RJ (2006) Consistent sets of spectrophotometric chlorophyll equations for acetone, methanol and ethanol solvents. Photosynth Res 89:27-41

Sellner KG (1997) Physiology, ecology, and toxic properties of marine cyanobacteria blooms. Limnol Oceanogr 42: 1089-1104

Sharp JH (1977) Excretion of organic matter by marine phytoplankton: Do healthy cells do it? Limnol Oceanogr 22:381-399

Slawyk G, Raimbault P (1995) Simple procedure for simultaneous recovery of dissolved inorganic and organic nitrogen in ${ }^{15} \mathrm{~N}$-tracer experiments and improving the isotopic mass balance. Mar Ecol Prog Ser 124:289-299 
Slawyk G, Raimbault P, García N (1998) Measuring gross uptake of ${ }^{15} \mathrm{~N}$-labeled nitrogen by marine phytoplankton without particulate matter collection: evidence of low ${ }^{15} \mathrm{~N}$ losses to the dissolved organic nitrogen pool. Limnol Oceanogr 43:1734-1739

Slawyk G, Raimbault P, García N (2000) Use of ${ }^{15} \mathrm{~N}$ to measure dissolved organic nitrogen release by marine phytoplankton (reply to comment by Bronk and Ward). Limnol Oceanogr 45:1884-1886

Sohm JA, Edwards BR, Wilson BG, Webb EA (2011) Constitutive extracellular polysaccharide (EPS) production by specific isolates of Crocosphaera watsonii. Front Microbiol 2:1-9

Taniuchi Y, Chen YL, Chen HY, Tsai ML, Ohki K (2012) Isolation and characterization of the unicellular diazotrophic cyanobacterium Group C TW3 from the tropical western Pacific Ocean. Environ Microbiol 14:641-654

Thoresen SS, Dortch Q, Ahmed SI (1982) Comparison of methods for extracting intracellular pools of inorganic

Editorial responsibility: Douglas Capone,

Los Angeles, California, USA nitrogen from marine phytoplankton. J Plankton Res 4: 695-704

Tripp HJ, Bench SR, Turk KA, Foster RA and others (2010) Metabolic streamlining in an open-ocean-fixing cyanobacterium. Nature 464:90-94

Valderrama JC (1981) The simultaneous analysis of total nitrogen and total phosphorus in natural waters. Mar Chem 10:109-122

> Wannicke N, Koch BP, Voss M (2009) Release of fixed $\mathrm{N}_{2}$ and $\mathrm{C}$ as dissolved compounds by Trichodesmium erythreum and Nodularia spumigena under the influence of high light and high nutrient (P). Aquat Microb Ecol 57: 175-189

Wood M, Van Valen M (1990) Paradox lost? On the release of energy-rich compounds by phytoplankton. Mar Microb Food Webs 4:103-116

Zehr JP, Waterbury JB, Turner PJ, Montoya JP and others (2001) Unicellular cyanobacteria fix $\mathrm{N}_{2}$ in the subtropical North Pacific Ocean. Nature 412:635-638

Submitted: June 12, 2012; Accepted: February 17, 2013 Proofs received from author(s): April 8, 2013 